\title{
DE TRANQUILLITATE ANIMI COMO EXERCÍCIO ESPIRITUAL
}

\author{
ANGÉLICA CHIAPPETTA* \\ Faculdade de Filosofia, Letras e Ciências Humanas \\ da Universidade de São Paulo
}

\begin{abstract}
RESUMO: Este trabalho trata do diálogo epistolar de Sêneca De tranquillitate animi como exemplo de obra filosófica helenístico-romana. Para o estoicismo a filosofia é uma ars uiuendi e requer exercitação contínua que pode ser vista como uma "medicação interminável" em busca do beate uiuere.
\end{abstract}

PALAVRAS-CHAVE: Sêneca; estoicismo; filosofia helenístico-romana.

Quando, durante a organização desta Semana de Estudos sobre Sêneca, apresentei o De Tranquillitate Animi como tema de minha fala, foi observado que a escolha seria oportuna, pois, sendo esse um "tratado filosófico", os vários gêneros produzidos por Sêneca estariam representados. Essa observação levanta duas questões: qual a pertinência de uma professora de "letras" analisar um texto filosófico e qual a distinção, para os antigos, entre um texto literário e um texto filosófico?

Atualmente a Filosofia e as Letras são saberes separados, ocupam diferentes departamentos universitários e implicam distintos modelos de trabalho. Para ser reconhecido como Filósofo hoje, alguém deve demonstrar uma formação específica que aponta não só para um conjunto de informações articuladas, mas também para uma maneira de tratar essas informações e de produzir novas análises. O filósofo atual, cumprindo as exigências do trabalho filosófico, vê-se reconhecido pelos seus pares. O mesmo poderia ser dito a respeito do sociólogo, do antropólogo, do historiador.

É interessante lembrar que àqueles que se dedicam aos estudos de Letras falta um nome único e específico: literato, crítico literário, ou quem sabe, "letrista", "letrólogo", "letrófilo". Talvez não seja demais dizer que um certo exagero pragmá- 
tico e positivista vê no trabalho com as Letras algum tipo de saber superficial que trata da maquiagem do discurso e não do conteúdo propriamente dito. Talvez, desse ponto de vista, um estudioso das Letras, quando analisa um texto filosófico, detém-se na forma, na aparência ou naquilo que a Retórica Antiga chamava de elocução do texto, sem alcançar a verdade que estaria por trás das palavras e que só seria atingida pelo trabalho específico do filósofo.

Assim, a tarefa do estudioso de Letras seria mais conveniente para os textos literários. No caso da chamada Literatura Latina, essa restrição é um problema, pois costuma-se agrupar nessa rubrica tantos os poemas de Catulo, quanto os discursos de Cícero, as monografias históricas de Salústio e os tratados filosóficos de Sêneca. Lidamos hoje com uma classificação incômoda: colocamos num mesmo grupo as obras de Catulo, Cícero, Salústio e Sêneca e damos a esse grupo um nome que contemporaneamente não engloba a diversidade agrupada. Não é o caso de se discutir aqui, mas é sempre bom lembrar que a atribuição da etiqueta "literatura" a essas obras antigas é sempre anacrônica e problemática já que o conceito não é universal e começa e ser formulado pelo menos no séc. XVIII d.C..

Aquilo que chamamos de Filosofia Antiga restou para nós na forma de textos que apresentam características formais marcantes. Seja, por exemplo, o diálogo platônico: é um tipo de discurso filosófico que apresenta personagens dialogando numa situação, talvez pouco natural, em que uma das personagens fala muito mais do que qualquer uma das outras. Não é necessário acreditar que Sócrates efetivamente participou de todas as conversas tal e qual Platão nos apresenta em seus diálogos. Talvez até fosse mais interessante pensar no diálogo como um discurso que imita não uma situação real, mas sim as regras de seu gênero: o que é impróprio num diálogo real (um dos interlocutores falar muito mais do que qualquer outro) é conveniente no gênero diálogo filosófico.

Aqui chegamos ao importante ponto de lembrar que a divisão dos saberes referida acima, não é hoje a mesma dos tempos antigos. Certamente um poema lírico não se confunde, para os antigos, ${ }^{1}$ com um diálogo filosófico; da mesma maneira que um poema lírico não se confunde com uma monografia histórica ou com um poema épico. Cada discurso deve seguir as regras específicas de ordenação do gênero ao qual pertence. Há na Antigüidade uma arte de produzir discursos ordenados, a Retórica, que foi sendo formulada ao longo de séculos até ocupar, no mundo helenístico-romano, o lugar de instância teorizadora dos discursos em geral. O conjunto de meu trabalho como pesquisadora está inserido numa linha de pesquisa que pretende discutir a Retórica Antiga como essa instância teorizadora e analítica dos discursos. 
Desde Aristóteles se diz que o orador tem três fontes de provas para obter a persuasão: o discurso propriamente dito (logos), o caráter (ethos) com que se apresenta e as paixões (pathe) que demonstra e que consegue produzir no público. Portanto, além da preocupação mais evidentemente argumentativa, a Retórica estuda também as paixões humanas com o objetivo de utilizá-las na elaboração dos discursos. É o que se diz no segundo capítulo do Livro I da Retórica aristotélica: dado um assunto, o orador deve conseguir obter, em relação a ele, tudo o que for capaz de gerar persuasão; além de argumentos, portanto, o orador deve conhecer as paixões humanas para poder utilizálas convenientemente. Os primeiros dezessete capítulos do Livro II de Retórica muitas vezes são chamados de "Retórica das Paixões" (Aristote, 1988). As paixões são também discutidas nos tratados filosóficos, como é o caso presente, e é com o interesse de estudá-las nos discursos que apresento aqui algumas notas preliminares para a leitura do De Tranquillitate Animi.

Retoricamente, pode-se entender as Cartas a Lucilio de Sêneca como exemplo de um gênero filosófico, a epístola, em que se simula a falta de elaboração formal própria das boas correspondências entre amigos para assim poder discutir preceitos estóicos. Enquanto no diálogo filosófico a simulada presença física dos interlocutores, conversando juntos, coloca-os numa suposta situação de igualdade, as cartas, em geral, apresentam uma hierarquia em que uma das partes aparece respondendo perguntas, explicitamente ensinando um discípulo e ocupando, assim, o lugar de mestre.

O De Tranquillitate Animi pode ser visto como um "diálogo epistolar" entre Sêneca e seu discípulo Sereno (nome interessante para um interlocutor nesse diálogo). O diálogo filosófico simula uma conversa entre pessoas interessadas em discutir; a epístola uma carta-resposta de um mestre a um discípulo que, trazendo um assunto para observação, acaba por receber algum tipo de preceito do mestre. A participação do discípulo fica aqui implícita, sendo percebida apenas por alguma referência do mestre.

O presente "diálogo epistolar" é composto de duas cartas: uma de Sereno e outra, em resposta à primeira, de Sêneca. Sereno, já formado na doutrina estóica, escreve a Sêneca, seu mestre, solicitando esclarecimentos:

Sereno: A mim que me examinava a mim mesmo, certos vícios revelavam-se, Sêneca, tão evidentes, que eu os poderia ter à mão; outros, no entanto, mais obscuros e recônditos mostravam-se; outros, ainda, havia descontínuos, mas reincidentes a intervalos, os quais eu inclusive reputaria os mais molestos deles, à semelhança de inimigos que vagueiam e assaltam em momentos propícios, em relação aos quais 
não se pode nem estar preparado, tal qual na guerra, nem seguro, tal qual na paz. No entanto, a disposição que depreendo em mim (pois, por que razão não confessaria a ti, como a um médico, a verdade? [grifo nosso]) é sobretudo, a de nem estar francamente livre dos meus ódios e temores passados nem, ao contrário, a eles continuar ligado. Posto não seja o pior de todos, ainda assim, é extremamente lamentável e impertinente o estado em que me encontro: nem estou doente nem saudável [grifo nosso]. Nem é o caso de dizeres que são tenros os princípios de todas as virtudes, e que essas com o tempo adquirem consistência e robustez. Não ignoro também que aquilo que se reveste de aparência; digo a dignidade, a fama de eloqüência, e o que quer que vem segundo o sufrágio alheio - cresce com o tempo; e que tanto as coisas que alcançam verdadeiros méritos como as que, para agradar, seduzem por falsa aparência, esperam o perpassar dos anos até que o tempo lhes traga cor. Mas eu receio que o hábito, que consolida as coisas, crave-me mais fundo este vício: o longo trato faz-nos tomar gosto tanto do mal como do bem. Em que consiste essa inconstância da alma (animus) que, indecisa, nem se inclina resolutamente à retidão nem à depravação, não te posso dizer de uma só vez, mas sim por partes. Direi o que me acontece; tu acharás o nome para a doença [grifo nosso] (De tranq. an. I,1-4). ${ }^{2}$

Fazendo um auto-exame, Sereno conclui que possui três tipos de vícios: aqueles que ele reconhece facilmente e que estão presentes continuamente, outros só percebidos com maior atenção e outros, ainda, que aparecem inadvertida e surpreendentemente quando menos são esperados. Em relação aos dois primeiros Sereno não parece ter problemas, pois conta com os antídotos de sua formação estóica. Os últimos sim são vícios que o molestam. Afinal, como pode alguém já formado na doutrina ainda apresentar esses tropeços? Sereno fala a Sêneca como a um médico: não está doente nem saudável. Quando doente, ou seja, antes de completar sua formação estóica, permanecia continuamente atento a seus vícios. Terminada a formação, pensava poder estar seguro e não mais ser surpreendido pelos seus próprios defeitos. No entanto, não é o que acontece e ele sofre. Solicita, assim, um diagnóstico a Sêneca: "direi o que me acontece; tu acharás o nome para a doença".

Para um leitor pouco familiarizado com a Filosofia Antiga, ${ }^{3}$ pode parecer estranho que uma carta como a de Sereno faça parte de um tratado filosófico; e mais, pode parecer estranho que a queixa e a solicitação de um diagnóstico e de remédios sejam assunto da Filosofia. No entanto, no mundo helenístico-romano, a 
Filosofia não consiste no ensino de uma teoria abstrata, ou na exegese de textos, mas numa "arte de viver", ${ }_{4}^{4}$ numa atitude concreta que engloba toda existência. O ato filosófico não se situa apenas na ordem do conhecimento; é um progresso que nos torna melhores. Nesse sentido, os antigos chegam a falar em "conversão" a uma determinada doutrina filosófica, o que afeta toda vida de quem a executa e faz passar de um estado de vida inautêntico, que leva ao sofrimento, a um estado de vida autêntico, no qual o homem atinge a visão exata do mundo e de si mesmo (Hadot, 1987, p.15).

As escolas helenístico-romanas dizem que a principal causa de sofrimento para os homens são as paixões, entendidas como desejos desordenados ${ }^{5}$ e/ou crenças exageradas ${ }^{6}$ que levam à inquietação que, por sua vez, impede que o homem viva verdadeiramente. A filosofia aparece, então, como uma "terapêutica das paixões". ${ }^{7}$ Cada escola tem seu método terapêutico próprio que sempre deve levar, quando bem aplicado, a uma transformação profundo da maneira de ser e de ver.

Para os Estóicos, todo o mal dos homens vem de eles procurarem obter e guardar os bens que estão arriscados a não conseguir ou a perder, e de procurarem evitar os males que não podem evitar. A filosofia deve educar o homem para que não busque atingir outro bem senão o que pode obter e para que tente evitar apenas o mal que pode evitar. "Passa-se de uma visão 'humana' da realidade, visão na qual os valores dependem das paixões, a uma visão 'natural' das coisas que recoloca cada acontecimento na perspectiva da natureza universal" (Hadot, 1987, p.17). A visão "humana" do mundo depende das paixões, ou seja, daquilo que os Estóicos consideram uma alteração da parte diretriz da alma. Essa alteração tem origem numa falha voluntária da razão que, em lugar de permanecer fiel à sua própria natureza e de se ligar com firmeza às suas próprias normas, julga de uma maneira errônea. ${ }^{8}$ Passar da visão "humana", errônea, para a visão "natural" é tarefa difícil, mas os Estóicos acreditam que à força de exercícios pode-se chegar a usar a paixão, reduzir os afetos e, não podendo suprimi-los inteiramente, colocá-los num nível tolerável.

O método terapêutico estóico passa, assim, por esses exercícios que Pierre Hadot qualifica de "espirituais" (Hadot, 1987, p.17), pois, como explica, tais exercícios envolvem ao mesmo tempo o pensamento, o intelecto e a ação prática. Talvez fosse mais conveniente chamá-los de "exercícios do ânimo", o que evitaria sentidos hoje atribuídos ao termo "espírito" e estaria mais próximo do animus latino que, conforme usado por Cícero e Sêneca, por exemplo, indica a parte do ser humano que guarda a razão e que comporta as atividade intelectuais, as do pensamento, as da observação do mundo e as das atitudes práticas. 
Filo de Alexandria traz duas listas de "exercícios espirituais" que, embora não sejam idênticas, apresentam o panorama de uma terapêutica de matiz estóicoplatônico (Hadot, 1987, p.18-9). Uma dessas listas enumera os seguintes exercícios: a busca (zetesis), o exame aprofundado (skepsis), a leitura, a audição, a atenção (prosoché), o domínio de si (enkrateia), a indiferença às coisas indiferentes. A outra traz: as leituras, as meditações (meletai), ${ }^{9}$ as terapias das paixões, ${ }^{10}$ as lembranças do que é bom, o domínio de si (enkrateia), o cumprimento dos deveres. Para os Estóicos, filosofar é exercitar-se em viver, reconhecendo-se parte do um cosmos animado pela razão, renunciando a desejar o que não depende de nós e atendo-se ao que depende de nós, ou seja, a ação correta, conforme a razão (Hadot, 1987, p.25).

Ao escrever sua carta a Sêneca, Sereno apresenta-se como alguém que está exercitando um exame aprofundado (skepsis). ${ }^{11}$ Percebe em si o sofrimento e para tentar suprimi-lo passa a descrever seus sintomas. Primeiramente fala da sua relação com o luxo, sempre condenado pela doutrina estóica. Sereno diz organizar sua vida cotidiana e sua casa sem luxo; no entanto, ao freqüentar lugares onde está presente, o luxo toca-lhe o ânimo (praetingit animum):

Contra esse luxo, mais facilmente levanto o pensamento que os olhos; e assim retrocedo não pior, mas mais triste, e em meio àquelas minhas frugalidades não ando tão satisfeito, e me vêm o remorso e a dúvida, se seriam melhores aquelas coisas. Nenhuma delas me altera. Todas, contudo, abalam-me (De tranq. an. I,8).

Em seguida fala de outro ponto importante da doutrina estóica: a participação na vida pública. Os Estóicos consideram que o verdadeiro sábio não deve fugir dos assuntos e dos afazeres públicos, e é esse preceito que Sereno tenta seguir:

Agrada-me seguir a força dos preceitos e entrar na vida pública; agrada-me procurar as honras e os fasces, ${ }^{12}$ não evidentemente seduzido pela púrpura ou pela vara do litor, mas a fim de que eu venha a me encontrar mais preparado e mais útil frente a amigos e parentes e a todos os cidadãos e, portanto, a todos os mortais: disposto, inexperiente, sigo Zenão, Cleantes, Crisipo, nenhum dos quais entrou na vida pública e nenhum, todavia, a deixou. Quando algo atinge minha alma não acostumada aos embates (aliquid animum insolitum arietari percussit), quando algo ocorre indigno, como em toda vida humana muitas coisas são, ou de difícil solução, ou quando muito tempo solicita-me algo que não merece demoradas aprecia- 
ções, volto ao ócio e, assim, como acontece aos animais, ainda que fatigados, retorno mais veloz para casa. Agrada-me, entre as paredes da casa, novamente encerrar a vida: que ninguém me tire um só dia, pois ninguém me haverá de ressarcir de tanto dispêndio, ela que em si própria esteja apoiada, que se cultive, que não persiga nada alheio, que contemple algo para criticar; que seja amada a tranqüilidade livre de preocupação pública e privada. Mas, logo que uma leitura mais recomendável exalta-me a alma (ubi lectio fortior erexit animum) e exemplos nobres atiçam-me seus aguilhões, agrada-me ir ao foro, obsequiar a um com a minha palavra, a outro com o meu trabalho que, não vindo, ainda, a servir a nada, será feito, ao menos, com a intenção de ser útil (De tranq. an. I,10-1).

Sereno descreve aqui, de modo impressionado e impressionante, suas tentativas de execução dos preceitos estóicos. Mostra-se inclusive tentado a executar alguns "exercícios espirituais" como, por exemplo, a leitura que, no entanto, eriçalhe o ânimo e o faz partir novamente para a vida pública.

Por fim, Sereno, lembre-se que já doutrinado, fala de sua relação com o discurso (oratio), que os Estóicos pretendiam o mais afastado possível da grandiloqüência e do excesso de ornato, seguindo unicamente o fluxo espontâneo das idéias ${ }^{13}$ e renunciando a buscar glória a partir da fama como orador:

Nos estudos penso, por Hércules, ser melhor observar as próprias matérias e falar movido por elas, a elas deixando ir as palavras, de maneira que, por onde quer que tenham conduzido aquelas, siga-as espontaneamente o discurso. De que serve compor obras destinadas a durar séculos? Acaso não desejas tu fazê-lo para que a posteridade não silencie sobre ti? Para a morte nasceste: menos enfado tem o funeral silencioso. Pois então escreve para ocupar o tempo em teu proveito, com estilo simples e sem afetação: de menor labor necessitam os que trabalham para o dia. Quando minha alma novamente se alça a pensamentos elevados (rursus, ubi se animus cogitationum magnitudine leuanit) é ambiciosa em relação às palavras e, como aspira a coisas mais altas, assim lhe apraz falar e, à dignidade dos assuntos, eleva-se a linguagem. Esquecido então da lei e do juízo, de modo mais sublime sou transportado e já por boca não minha (De tranq. an. I,14-5).

Sereno faz aqui até uma rápida "auto-consolação", ao justificar o preceito estóico de simplicidade de elocução por um reconhecimento da condição finita do 
homem: já que a morte é certa, tentar evitá-la buscando o reconhecimento futuro da glória como orador é uma atitude passional e equivocada. Mesmo concorde com essa idéia, Sereno descreve-se como arrebatado e enlouquecido pela grandeza de certos pensamentos, tão mais elevados que colocam-no na desconfortante posição de não poder controlar sua boca.

Os sintomas apresentados por Sereno passam por algum movimento do ânimo: o luxo toca-lhe (praestingit) o ânimo, os acontecimentos da vida pública percutem (percussint) seu ânimo, a leitura exalta-lhe (erexit) o ânimo e a grandeza dos pensamentos eleva-lhe (leuauit) o ânimo. $\mathrm{O}$ ânimo, sede da razão humana, é responsável pelas escolhas de Sereno que parece não conseguir atingir o meio-termo virtuoso da doutrina moral aristotélica ${ }^{14}$ e, portanto, apresenta-se no desequilíbrio desqualificante de quem não consegue manter a ponderação. É, afinal, nessa inconstância no reconhecimento do ponto médio que se deve colocar o tormento de Sereno:

Para não prolongar mais tempo cada coisa, em todas me segue essa inconstância da boa intenção, inconstância em que temo escorregar pouco a pouco, ou, o que é mais inquietante, pender sempre como quem vai cair - e me pergunto então se talvez este meu caso seja mais grave do que eu próprio reconheço. Pois olhamos com afeto nossas coisas particulares, e a auto-estima (fanor) sempre nos prejudica o julgamento. Penso que muitos teriam podido chegar à sabedoria, se não pensassem já ter chegado, se não tivessem dissimulado em si certas coisas, se não tivessem passado por outras com os olhos fechados. Pois não é pela adulação alheia, mais do que pela nossa, que nos prejudicamos. Quem ousou dizer a si a verdade? Quem, entre multidões de louvadores e aduladores, muitíssimo não aprovou a si próprio? Assim então rogo, se tens algum remédio com que cesses essa minha flutuação, digno que julgues de deverte a tranqüilidade [grifo nosso]. Sei que não são perigosos esses movimentos de alma (motus animi), nem trazem algo de tumultuoso: para que eu te exprima em correta comparação o de que me queixo, digo-te que não sou agitado pela tempestade, mas pela náusea [grifo nosso]. Arranca, portanto, o que quer que isso seja de mal, e socorre ao que sofre à vista de terras (De tranq. an. I,16-8).

Sereno termina sua carta dizendo que, tendo-se já formado na doutrina estóica, sua aspiração é atingir a condição de sábio e faz esse exame profundo de si mesmo para evitar o erro, bastante comum, de considerar-se o que ainda não é e, 
portanto, acomodar-se a meio caminho da doutrinação. Declara-se não mais agitado pela tempestade das paixões, circulando nos extremos dos vícios, mas nauseado no que ele julga ser o virtuoso meio-termo próprio da razão. Avistando já a terra firme, pede ajuda para não morrer na praia.

Sêneca responde-lhe, em linguagem médica, com um diagnóstico sucinto:

Procuro há muito, por Hércules, eu próprio em silêncio, Sereno, o com que se parece tal estado de alma (affectum animi), e não vejo exemplo que mais se the aproxime do que o daqueles que desembaraçados de longa e grave doença, são impressionados por leves acessos de febre e, mesmo depois de afugentarem os resquícios desse mal, inquietam-se, todavia, com suspeitas e, já curados, estendem aos médicos o pulso e interpretam mal qualquer elevação de temperatura de seus corpos. Desses, Sereno, o corpo não está pouco são, mas pouco habituado à saúde, assim como no mar tranqüilo há também certa agitação, mesmo quando o movimento proveniente da tempestade se tenha amainado [grifo nosso]. ${ }^{15} \mathrm{E}$ assim não são necessárias aquelas coisas mais duras pelas quais já temos passado ${ }^{16}$ - a saber: resistir a ti mesmo, encolerizar-te, ameaçar-te -, mas é necessário aquilo que vem por último: que tenhas confiança em ti mesmo e creias que vás pela via reta, em nada desviado por pegadas transversais de muitos que correm por aqui, por ali, alguns dos quais se desviam junto à mesma via. O que desejas aliás é coisa grande e elevada, e próxima do divino: não ser abalado. A esse equilibrio de alma os gregos chamam de euthymia, sobre o que há um volume egrégio de Demócrito; quanto a mim chamo de tranqüilidade [grifo nosso]: pois não é necessário imitar e traduzir as palavras segundo a forma dos gregos; trata-se, não do aspecto, mas da idéia mesma, que tem de ser assinalada por algum nome que deve ter o significado da denominação grega. Procuraremos saber, portanto, de que modo a alma poderá ir sempre com curso igual e favorável e, sendo mais propicia a si mesma, atentar para as suas coisas, não interrompendo esse gáudio, mas permanecendo em estado plácido, sem se exaltar alguma vez nem se deprimir. Isso será a tranqüilidade [grifo nosso]. Procuraremos de que modo, em geral, se possa chegar a ela; tomarás tu quanto quiseres do remédio público (De tranq. an. II,1-4).

Sereno deseja o que está próximo do divino e somente o verdadeiro sábio estóico poderia atingir por completo: não ser abalado, ou seja, a ataraxia. Afinal, esse sábio é apresentado como modelo pela doutrina estóica para arrancar o neófito 
da tempestade do vício; no entanto, mesmo quando a tempestade já se acalmou, há certa agitação no mar. $\mathrm{O}$ ânimo de quem se formou na doutrina, tendo como modelo o sábio, deve, na verdade, contentar-se com um equilíbrio que os gregos chamam de euthymia e os latinos de tranquillitas. A tranqüilidade é o que permite ao ânimo seguir num curso sempre constante e favorável. Para mantê-lo é preciso que o ânimo mantenha-se no ponto que lhe é mais propício e é o mais adequado às suas constituição e características particulares ${ }^{17}$. A doutrina estóica traz preceitos gerais (por exemplo, sobre o luxo, sobre a vida pública e o discurso) que não podem ser aplicados cegamente, sem considerar a medida própria e decorosa de cada um. Apenas ponderado por essa medida é que o preceito pode levar a um estado plácido, sem exaltação nem depressão.

Portanto, o diagnóstico de Sêneca em relação a Sereno é esse: trata-se de um caso de distimia, conseqüência de certos exageros de Sereno na aplicação dos preceitos estóicos: ele repudiou radicalmente o luxo, colocando-se num ponto que não lhe é possível suportar confortavelmente; entregou-se extremadamente à vida pública, sem considerar que a trepidação social pode romper o equilíbrio moral da mesma forma que a solidão, quando talvez fosse melhor lembrar que a solidão e o mundo são antídotos mútuos; obrigou-se a suprimir qualquer ornamentação do discurso, inclusive aquelas que, no seu ânimo, acompanham os pensamentos elevados. O resultado é o que ele mesmo declarou: "não sou agitado pela tempestade, mas pela náusea" (non tempestate uexor sed nausea). A náusea é a tradução fisiológica do taedium uitae, descontentamento da vida, que lembra o estado de pessoas gravemente doentes. Os desejos do entediado, encerrados por limites que não lhes são próprios ou convenientes, estrangulam-se a si mesmos e, em conseqüência, o doente é afligido por um vago sentimento de culpabilidade ${ }^{18}$ em relação ao passado e de medo em relação ao futuro. Isso leva à suspensão da atividade que, por sua vez, coloca o doente num insuportável face a face consigo mesmo:

Daqui aquele tédio e descontentamento de si, a agitação da alma que nunca pára, e a triste e aflita paciência de sua própria inanição, sobretudo quando envergonha confessar as causas e o pudor mantém dentro os tormentos: ${ }^{19}$ encerrados nesses apertos, os desejos estrangulamse a si mesmos sem saida; daí a tristeza e abatimento e as mil flutuações da mente incerta [grifo nosso], a quem as esperanças iniciadas mantêm suspensa, as fracassadas mantêm triste; daí aquela disposição dos que detestam seu ócio e se queixam de nada ter para fazer, e a inveja inimicíssima dos sucessos alheios (pois a infeliz indolência alimenta a inveja, e desejam que todos se destruam, porque eles não puderam 
progredir); dessa aversão aos progressos alheios e do desespero pelos fracassos próprios, a alma irrita-se contra a fortuna e se queixa do século, retraindo-se pelos cantos e absorvendo-se em sua pena, enquanto está farta e desgostosa de si mesma. Com efeito, a alma humana é, por natureza, ágil e dada a movimentos. Agradável lhe é todo assunto que a excite e a distraia (De tranq. an. II,10-1).

A conseqüência do desequilíbrio do ânimo, da distimia, é "sentir-se mal na própria vida”. Jackie Pigeaud, estudando a relação da alma e do corpo da tradição médico-filosófica antiga, lembra que este "desgosto da vida" pode ser relacionado à tristeza e à melancolia, entendidas como doenças da alma e do corpo respectivamente. Apresenta o problema da euthymia não só do ponto de vista da teoria estóica das paixões, mas principalmente dentro da imprecisão e do fluxo de uma outra tradição que a trata sob um aspecto mais especificamente médico com o nome de melancolia (Pigeaud, 1989, p.443-521). Demócrito teria sido o primeiro a dar ao termo euthymia a dignidade de um conceito filosófico. Os antigos fizeram circular uma pseudo-correspondência entre Hipócrates e Demócrito (Hippocrate, 1989), reafirmando que a reflexão sobre a eutimia é a ponte mais avançada da filosofia para a medicina. O filósofo não se ocupa da melancolia senão por sua versão psicológica, mas não deixa de propor remédios para esse mal que sempre afeta o corpo. Tratando da eutimia, o filósofo encontra uma zona de reflexão nos limites entre o problema filosófico da felicidade (eudaemonia) e o problema médico da apathia.

É assim que, tendo diagnosticado o problema de Sereno, Sêneca propõe-lhe remédios próprios a um corpo que não está habituado à saúde. Do ponto de vista da cura não são necessários remédios violentos; a primeira necessidade é que o doente restabeleça a confiança em si, o primeiro gesto é confortar, dar esperança para que o doente encontre a eutimia. Esta última é para o ânimo o que a apatia é para o corpo, mas distingue-se por não ser apenas ausência de dor; ela é positiva. Por outro lado, ela se assemelha à felicidade, mas se distingue desta por não prestar atenção apenas em princípios teóricos, mas também, e principalmente, no como colocar o ânimo naquela rota contínua e confortável.

A carta de Sêneca termina com uma lista de remédios para esta terapêutica do como. Um dos primeiros efeitos do tédio é tirar da sociedade o indivíduo e isolálo numa misantropia excessiva; o remédio é reconciliá-lo com os outros, pois esse é o modo de reconciliá-lo consigo mesmo. É preciso retomar a humanitas, preocuparse com os negócios públicos (De tranq. an. III-V). Para cumprir esta primeira tarefa 
é preciso conhecer-se a si mesmo, o que significa conhecer seu caráter, seu temperamento, seu engenho natural, seu decoro particular (ib. VI). É preciso procurar amigos de agradável conversação, o mais afastados possível dos vícios (ib. VII). Em seguida vem o cuidado em relação ao patrimônio e à parcimônia (VIII-IX). Isso feito, trata-se então de um contínuo exercício de cuidado das paixões: suportar os males inevitáveis (ib. X), não desejar os bens que não são possíveis (ib. XII), moderar a relação entre ocupação e ócio (ib. XIII-XIV), não se indignar com os crimes impunes (ib. XV) ou com os maus destinos dos bons (ib. XVI), evitar a vida dissimulada (ib. XXVII). Essas últimas indicações são uma resposta aos sintomas descritos por Sereno em relação a sua tentativa de atuar na vida pública (ib. XI,10-1).

Esses remédios são, na verdade, "exercícios espirituais" a serem continuamente executados por Sereno. A cura estóica não é uma mudança peremptória e estanque, mas sim uma "medicação interminável” (Veyne, 1988) em que a observação e o exercício dos preceitos devem estar relacionados ao cuidado de si. Com isso, Sêneca espera que Sereno atinja a tranquillitas animi e suma a tristeza anímica decorrente do taedium. Há, no entanto, uma diferença entre a doença (aegritudo) e o tédio (taedium). A primeira é conseqüência de um erro de julgamento e depende das circunstâncias; o segundo tem causas indeterminadas que decorrem dos limites humanos ${ }^{20}$. Portanto, são duas as espécies de tristeza: uma pontual e determinada em que o doente se aborrece como o mundo, outra difusa e indeterminada em que o doente se aborrece consigo mesmo. A nausea e o taedium de Sereno têm semelhanças com a melancolia, que a medicina antiga via como um desequilíbrio dos humores corporais e cuja terapia usava o vinho como um dos elementos reguladores do calor do corpo.

Nenhum medicamento é bastante forte para salvar coisa tão frágil como a tranqüilidade se o ânimo vacilante não aplica cuidado assíduo (De tranq. an. XVII,12). A saúde do ânimo anda junto a do corpo. Explicitando essa referência médica, Sêneca termina sua lista de remédios prescrevendo medicamentos que parecem ter ação indistintamente anímica e corporal:

É preciso ser indulgente com o espírito (animus) e dar-lhe, de tempos em tempos, um repouso que lhe sirva de alimento e restauração. É preciso também passear por espaços abertos, para que o espírito (animus) se fortifique e se eleve a céu livre e em pleno ar; algumas vezes um passeio, uma viagem ou uma mudança de região darão vigor, ou mesmo um banquete e uma bebida em doses mais generosas. Às vezes também é preciso chegar até a embriaguez, não para 
que ela nos trague, mas para que nos acalme: pois ela dissipa as preocupações, revolve até o mais fundo da alma e a cura da tristeza assim como de certas enfermidades. E Líber ${ }^{21}$ foi chamado o inventor do vinho não porque solta a língua, mas sim porque libera a alma da escravidão das inquietações; restabelece-a, fortalece-a e a faz mais audaz para todos os esforços (De tranq. an. XVII,8).

\section{Notas}

* Professora Doutora de Língua e Literatura Latina do Programa de Pós-Graduação em Letras Clássicas e do Curso de Graduação da FFLCH-USP.

1 "Os antigos" é uma rubrica muito generalizante para indicar os gregos e romanos envolvidos e interessados no que hoje chamamos de "Literatura Antiga".

2 Todas as citações de Sêneca serão tiradas de SÊNECA. Sobre a tranqüilidade da alma. Tradução, notas e apresentação de José Rodrigues Seabra. São Paulo: Nova Alexandria, 1994. Nessa edição "alma" traduz o termo latino animus. No presente trabalho preferi usar o termo português "ânimo".

3 "Filosofia Antiga" é uma designação generalizante demais para apontar para um saber específico. Sócrates, Sêneca, Aristóteles, Crisipo, Cícero, Panécio, hoje chamados filósofos, talvez entendessem suas tarefas de modos distintos uns dos outros e, certamente, diferentemente do que hoje chamamos de tarefa de filósofo.

4 Arte de viver, ars uiuendi, techné tou biou. O termo "arte" é o mesmo que aparece em expressões como "arte retórica”, "arte poética”, "arte médica”, "arte de amar” e que, de forma geral, engloba atividades cuja execução depende do conhecimento e da manipulação de um conjunto de regras. Para produzir um discurso é preciso conhecer uma arte; para viver, também.

5 Os Estóicos entendem as paixões, e portanto o sofrimento humano, principalmente como desejos desenfreados.

6 Os Epicuristas entendem as paixões principalmente como crenças exageradas.

7 O primeiro sentido da palavra grega theurapeutés, terapeuta, é "aquele que cuida", daí o sentido de "servo e adorador de um deus", ou "aquele que cuida de alguma coisa". Daí, inclusive "médico", ou seja, "aquele que cuida dos doentes". No De uita contemplativa, Filo de Alexandria fala de um grupo de filósofos que se auto-denominavam "terapeutas": "O nome revela o projeto dos filósofos chamados de Terapeutas primeiramente porque a medicina (iatriké) de que fazem profissão é superior àquela que ocorre em nossas cidades - esta só cuida do corpo, mas a outra também cuida do psiquismo (psykas), vítima dessas doenças terríveis e difíceis de curar que são a pego ao prazer, a desorientação do desejo, a tristeza, as fobias, as invejas, a ignorância, o desajuste em relação ao que existe e a multidão infinita de outras patologias (pathon) e sofrimentos" (Ouaknin, 1996, p.13). 
8 Segundo Crisipo, toda paixão comporta dois julgamentos errôneos: um sobre a natureza de um evento, outro sobre a atitude que deve ser adotada a seu respeito. Um homem experimenta uma paixão quando julga erradamente se um evento é bom ou mal e se convém ser afetado ou não (cf. Voelke, 1981).

9 Meditatio é o termo latino que designa "exercício preparatório", principalmente o dos retores, como as controuersiae e as suasoriae (exercícios escolares em que o aluno deve compor discursos judiciários e deliberativos, respectivamente). Um dos exercícios estóicos que se encaixa nessa categoria é a praemeditatio mortis, "pré-exercício da morte", com o intuito de treinar o iniciado a morrer bem, já que a morte á inevitável.

10 Como já dito, a paixão comporta um julgamento sobre a natureza do evento e um julgamento sobre a atitude que convém adotar a seu respeito. Os dois julgamentos são errôneos, mas, para curar a paixão, suprimir o segundo é mais eficaz. A tristeza, por exemplo, decorre de alguém ter julgado que um mal lhe aconteceu e que é justo padecer por causa desse mal. Suprimir o primeiro erro de julgamento é tarefa trabalhosa e demorada. Já o segundo é mais fácil de ser suprimido e é essa a tarefa das "consolações", que são discursos em que se mostra que toda paixão é um estado irracional ou discordante, não só eliminando as proposições falsas às quais o pensamento deu assentimento, mas também apresentando outras proposições no lugar das condenadas (cf. Voelke, 1981).

11 De tranq. an. I, 1: Inquirenti mihi in me "A mim que me examinava a mim mesmo".

12 Honores são os cargos públicos. Fasces: feixe de varas com que os litores acompanhavam os cônsules, como insígnia do direito que estes tinham de punir.

13 As Cartas a Lucílio de Sêneca são um exemplo de esforço do orador em produzir uma aparência de simplicidade e espontaneidade afastadas do trabalho de elocução.

14 Ética a Nicômaco, 1106b-25: "Analogamente, no que tange às ações também existe excesso, carência e meio-termo. Ora, a virtude diz respeito às paixões e ações em que o excesso é uma forma de erro, assim como a carência, ao passo que o meio-termo é uma forma de acerto digna de louvor; e acertar e ser louvado são características da virtude. Em conclusão, a virtude é uma espécie de mediania, já que, como vimos, ela põe sua mira no meio-termo" (Aristóteles, 1984, p.73).

15 É interessante notar como Sêneca repropõe as duas metáforas de Sereno: a médica e a náutica. Afinal, assim como curar doentes e dirigir navios, viver é uma atividade para quem domina a arte.

16 Sereno já passou pela fase inicial da doutrinação estóica e, portanto, não precisa mais dos remédios fortes que eram necessários quando ainda não tinha qualquer domínio sobre suas paixões.

17 Cícero, no De Officiis I,95 ss., lembra a doutrina estóica sobre o decorum: há um decoro geral, que é comum a todos os homens e que faz com que esses se distingam dos outros seres animados. E há um decoro particular, que faz com que os homens distingam-se uns dos outros. A tranqüilidade do ânimo depende do reconhecimento e da atenção a esse decoro particular.

18 O termo "culpabilidade" é acrescentado por Jackie Pigeaud ao retomar a descrição da distimia (cf. Pigeaud, 1989, p.503-4). 
19 Lembrar que Sereno disse que, sem pudor, confessaria seus sintomas a Sêneca, como a um médico (cf. De tranq. an. I, 1).

20 O taedium seria decorrente da "inelutável necessidade de morrer" (Pigeaud, 1989, p.517).

21 Líber é um dos nomes de Baco.

\section{REFERÊNCIAS Bibliográficas}

ARISTOTE. L'homme de génie et la mélancolie. Traduction, présentation et notes de J. Pigeaud. Paris: Rivage, 1988.

ARISTÓTELES. Ética a Nicômaco. In: Os Pensadores. São Paulo: Abril Cultural, 1984. p. 45-236.

FOUCAULT, M. Tecnologías del yo. Barcelona: Paidós, 1990.

HADOT, Pierre. Exercices spirituels et philosophie antique. Paris: Études Augustiniennes, 1987.

HIPPOCRATE. Sur le rire et la folie. Préface, traduction et notes d'Yves Hersant. Paris: Rivage, 1989.

OUAKNIN, M.-A. Biblioterapia. São Paulo: Loyola, 1996.

PIGEAUD, J. La maladie de l'âme. Étude sur la relation de l'âme et du corps dans la tradition médico-philosophique antique. Paris: Les Belles Lettres, 1989.

RABINOW, P.; DREYFUS, H. Entrevista com Michel Foucault. In: Foucault, uma trajetória filosófica. Rio de Janeiro: Forense Universitária, 1995. p. 253-78.

SÊNECA. Sobre a tranqüilidade da alma. Sobre o ócio. Tradução, apresentação e notas de José Rodriques Seabra: São Paulo: Nova Alexandria, 1994. p. 11-73.

VEYNE, P. La medication interminable. In: SÉNÈQUE. De la tranquillité de l'âme. Paris: Rivage, 1988. p. 7-64.

VOELKE, A.-J. La fonction thérapeutique du logos selon Chrysippe. Études des Lettres. Lausanne, v. 4 (20), p.57-71, 1981.

CHIAPPETTA, Angélica. The De tranquillitate animi as an example of spiritual exercitation.

ABSTRACT: This paper deals with the senecan epistolar dialog De tranquillitate animi as an example of hellenistic-roman philosophical work. 
To stoicism philosophy is an ars uiuendi and requers a continous moral exercitation that can be seen as an "endless medication" in search of beate uiuere.

KEY WORDS: Seneca; stoicism; hellenistic-roman philosophy. 